Board of Governors of the Federal Reserve System

International Finance Discussion Papers

Number 467

May 1994

\title{
FISCAL POLICY COORDINATION AND FLEXIBILITY UNDER EUROPEAN MONETARY UNION: IMPLICATIONS FOR MACROECONOMIC STABILIZATION
}

Jay H. Bryson

NOTE: International Finance Discussion Papers are preliminary materials circulated to stimulate discussion and critical comment. References in publications to International Finance Discussion Papers (other than an acknowledgment that the writer has had access to unpublished material) should be cleared with the author or authors. 


\begin{abstract}
Some writers have proposed that under European Monetary Union fiscal policies should be coordinated to reduce the degree of fiscal activism required for macroeconomic stabilization. The paper shows that, in theory, fiscal policy coordination may lower the degree of fiscal flexibility needed to stabilize a common supply shock. However, fiscal policy coordination may raise the degree of fiscal flexibility needed to stabilize an asymmetric demand shock. These theoretical findings are supported by simulations performed with the Multi-Country Model of the Federal Reserve Board. The results suggest that fiscal policy coordination under EMU may require more fiscal activism rather than less. The results also show that, regardless of the shock, fiscal policy coordination among EMU members provides more macroeconomic stabilization to the United States. However, due to the small spillovers between the EC and the United States, the magnitude of this increased stabilization is relatively trivial.
\end{abstract}




\title{
Fiscal Policy Coordination and Flexibility Under European Monetary Union: Implications for Macroeconomic Stabilization
}

\author{
Jay H. Bryson ${ }^{1}$
}

\section{Introduction}

As the European Community lurches toward monetary union, fiscal policy issues continue to engender lively debate. ${ }^{2}$ Among others, these issues include the desirability of binding rules on fiscal deficits, and the role of fiscal policy in macroeconomic stabilization. The Delors Report, the original blueprint for European Monetary Union (EMU), advocated binding rules on fiscal deficits as a mechanism to insure fiscal discipline. However, critics have emphasized that to offset asymmetric shocks, individual members of a monetary union, who are subject to a common monetary policy and who cannot devalue vis-a-vis other members, should not be constrained by arbitrary deficit ceilings. ${ }^{3}$

Indeed, due to the assignment of community-wide monetary policy to price stability, fiscal policy may be the primary stabilization tool under EMU. ${ }^{4}$ Therefore, on one hand, authorities should have flexibility in fiscal policymaking to offset asymmetric shocks. On the other hand, unconstrained flexibility in fiscal policymaking may lead to problems of debt unsustainability. To enhance the stabilization role while limiting the potential for irresponsibility, many authors have argued that fiscal policies should be coordinated rather than limited by deficit ceilings. ${ }^{5}$ However, does fiscal policy coordination within a

\footnotetext{
The author is a staff economist in the Division of International Finance. This paper represents the views of the author and should not be interpreted as reflecting the views of the Board of Governors of the Federal running the MCM simulations. I also its staff. I would like to thank Jaime Marquez and Prakash Loungani for Hallett for helpful comments and also would like to thank Karen Johnson, Patrick Conway, and Andrew Hughes 2 For recent discussions of some fiscal istions. I am solely responsible for any remaining errors. (1990), Bovenberg, Kremers, and Masson (1991), Wyplosz (1991). Thyetary Union see Bredenkamp and Deppler See Melitz (1991) for a critical assessment of binding fisz (1991), Thygesen (1992), and Masson and Taylor (1993). that fiscal flexibility is desirable in the face of binding fiscal rules. Masson and Melitz (1991) demonstrate similar conclusion for the case of asymmetric shocks. 4 According to Articl price stability."

Currie (1992) notes that the need for fiscal coordination. Wyplosz (1991) also calls for on binding fiscal rules has been softened to the
} 
monetary union require less fiscal flexibility or yield greater macroeconomic stabilization relative to a regime of insular fiscal policymaking?

To our knowledge, this question has not been adequately addressed in the context of EMU. Masson and Melitz (1991) show that Germany may benefit from French fiscal tightening to offset exogenous ecu appreciation, and that France may benefit from German fiscal tightening to fight exogenous inflation. However, the authors do not address explicitly the relative desirability of fiscal flexibility when fiscal policies are coordinated. Likewise, Emerson, et al (1992) consider only the desirability of French fiscal flexibility in offsetting a French export demand shock. Hughes Hallett and Vines $(1991,1993)$ model a "hard" EMU in which monetary and fiscal policies both are chosen cooperatively. However, the authors do not address the relative desirability of fiscal flexibility when fiscal policies are not coordinated within a monetary union. Recently, Bryson (1994) has shown theoretically that to stabilize a common supply shock, a regime of fiscal policy coordination requires less fiscal flexibility than a regime of insular policymaking. However, to stabilize an asymmetric demand shock, more fiscal flexibility is needed under fiscal policy coordination. These results hold for flexible and fixed exchange rate regimes. However, the empirical implications for EMU are not addressed.

This paper has three objectives. First, it assesses the implications of fiscal policy coordination among EMU members for macroeconomic stabilization within those countries. Second, it ascertains whether a regime of fiscal policy coordination requires more or less fiscal flexibility than a regime of insular policymaking. Finally, it assesses whether fiscal policy coordination among EMU members is desirable from the perspective of the United States.

The theoretical results are tested by simulations performed with the Multi-Country Model (MCM) of the Federal Reserve Board. To focus on the role of fiscal policy in macroeconomic stabilization, the paper eschews the controversy regarding the effect of monetary union on fiscal discipline. Specifically, the paper analyzes a regime of insular 
fiscal policymaking and a regime of fiscal policy coordination in the face of two separate shocks. The paper focuses on the degree of flexibility these regimes require to respond optimally to the shocks and the degree of macroeconomic stabilization the regimes provide.

In the simulations, EMU is represented by Germany, France, the United Kingdom, and Italy. Two separate shocks are considered: a common supply shock, represented by a ten percent increase in the price of oil, and an asymmetric demand shock, represented by an increase in German private consumption equal to one percent of GDP. In the case of the oil price shock, the paper finds that fiscal policy coordination causes a reduction in the European-wide variance of government spending. Thus, fiscal policy coordination, in addition to being welfare-superior to insular fiscal policymaking, lowers the required degree of fiscal flexibility. Stabilization of the asymmetric demand shock under fiscal policy coordination requires higher variance in European-wide government spending. Although fiscal policy coordination is welfare-superior to insular fiscal policymaking, a consequence of the former regime is its higher required degree of fiscal flexibility.

The paper is organized as follows: Section 2 demonstrates theoretically that fiscal policy coordination may reduce the need for fiscal flexibility in the face of a common supply shock, but may increase the need for fiscal flexibility in the face of an asymmetric demand shock. Section 3 describes the simulations that test this theoretical proposition and Section 4 presents the simulation results. Section 5 offers conclusions.

\section{Theory}

Consider two countries with a fixed bilateral exchange rate. These interdependent countries can be represent by the following reduced-form model: ${ }^{6}$

\footnotetext{
${ }^{6}$ The reduced-form expressions represent a multi-country model which includes the domestic country, the foreign country, and the rest-of-the-world. However, for analytical convenience, rest-of-the-world variables are suppressed in the reduced-form expressions. As in DeGrauwe (1990), a domestic fiscal expansion under high capital mobility has an ambiguous effect on foreign output and vice versa. An increase in domestic government spending raises domestic income and the domestic interest rate. Through the trade account, an increase in domestic income raises foreign income. Under a fixed exchange rate, the increase in the domestic interest rate forces the foreign country to raise the foreign interest rate thereby reducing foreign income. Assuming that

(Footnote continues on next page)
} 


$$
\begin{gathered}
4 \\
\mathrm{y}=\alpha_{1} \mathrm{~g}-\alpha_{2} \mathrm{~g}^{*}-\chi+\mu \\
\mathrm{y}^{*}=-\alpha_{2} \mathrm{~g}+\alpha_{1} \mathrm{~g}^{*}-\chi-\mu
\end{gathered}
$$

where $\mathrm{y}$ is output, $\mathrm{g}$ is government spending, $\chi$ is a common supply shock, and $\mu$ is a demand shock that switches expenditure from the foreign good to the domestic good, hereafter referred to as an asymmetric demand shock. The asterisk represents a foreign variable. Assume that $\alpha_{1}>\alpha_{2}$, that is, fiscal policy has a larger effect at home than abroad.

The current account of the balance of payments can be written

$$
\begin{aligned}
& \mathrm{CA}=-\beta_{1} \mathrm{~g}+\beta_{2} \mathrm{~g}^{*}+\beta_{3} \mu \\
& \mathrm{CA}^{*}=\beta_{2} \mathrm{~g}-\beta_{1} \mathrm{~g}^{*}-\beta_{3} \mu
\end{aligned}
$$

where $\mathrm{CA}$ is the current account. By raising domestic income, a domestic fiscal expansion induces a domestic current account deficit and a foreign current account surplus. However, $\beta_{1}>\beta_{2}$ because some of the increased domestic spending falls on goods from the rest-of-theworld.

Each country pursues an internal target, output, and an external target, the current account. The social loss functions are ${ }^{7}$

$$
\begin{gathered}
\mathrm{U}=(\mathrm{y})^{2}+\omega(\mathrm{CA})^{2} \\
\mathrm{U}^{*}=\left(\mathrm{y}^{*}\right)^{2}+\omega(\mathrm{CA})^{*}
\end{gathered}
$$

where $\omega$ is the weight society places on the current account. In response to stochastic disturbances, fiscal policymakers change government spending to minimize deviations of output and the current account from target levels (here normalized to zero).

Under a regime of insular fiscal policymaking, that is, under a Nash regime, each policymaker takes the policy of the other country as given. Fiscal policy reaction functions can be obtained by minimizing (3) with respect to $g$ and $\left(3^{*}\right)$ with respect to $g$. When solved simultaneously, the reaction functions yield optimal fiscal policies which, when

(Footnote continued from previous page) the interest rate effect dominates the trade account effect, a domestic fiscal expansion reduces foreign income. A foreign fiscal expansion has analogous effects. Bryson (1994) develops a simple fixed exchange rate model in which fiscal policy has a beggar-thy-neighbor effect also.

7 Frankel and Rockett (1988) and De Grauwe (1990) use similar social loss functions. 
substituted into (1), $\left(1^{*}\right),(2)$, and $\left(2^{*}\right)$, yield expressions for outputs and current accounts. In response to a common supply shock, the Nash equilibrium fiscal policies, and resulting expressions for outputs and current accounts are

$$
\begin{gathered}
\mathrm{g}=\mathrm{g}^{*}=\frac{\alpha_{1} \chi}{\alpha_{1}\left(\alpha_{1}-\alpha_{2}\right)+\omega \beta_{1}\left(\beta_{1}-\beta_{2}\right)}>0 \\
\mathrm{y}=\mathrm{y}^{*}=\frac{-\omega \beta_{1}\left(\beta_{1}-\beta_{2}\right) \chi}{\alpha_{1}\left(\alpha_{1}-\alpha_{2}\right)+\omega \beta_{1}\left(\beta_{1}-\beta_{2}\right)}<0 \\
\mathrm{CA}=\mathrm{CA}^{*}=\frac{-\alpha_{1}\left(\beta_{1}-\beta_{2}\right) \chi}{\alpha_{1}\left(\alpha_{1}-\alpha_{2}\right)+\omega \beta_{1}\left(\beta_{1}-\beta_{2}\right)}<0
\end{gathered}
$$

A common supply shock initially lowers output in both countries. Fiscal policymakers in both countries respond with expansionary fiscal policies that raise output and produce current account deficits (with the rest-of-the-world). Policymakers cannot completely stabilize output and the current account because the number of targets exceeds the number of instruments.

Under fiscal policy coordination, policymakers minimize the unweighted sum of the social loss functions yielding the following results:

$$
\begin{gathered}
\mathrm{g}=\mathrm{g}^{*}=\frac{\left(\alpha_{1}-\alpha_{2}\right) \chi}{\left(\alpha_{1}-\alpha_{2}\right)^{2}+\omega\left(\beta_{1}-\beta_{2}\right)^{2}}>0 \\
\mathrm{y}=\mathrm{y}^{*}=\frac{-\omega\left(\beta_{1}-\beta_{2}\right)^{2} \chi}{\left(\alpha_{1}-\alpha_{2}\right)^{2}+\omega\left(\beta_{1}-\beta_{2}\right)^{2}}<0 \\
\mathrm{CA}=\mathrm{CA}^{*}=\frac{-\left(\alpha_{1}-\alpha_{2}\right)\left(\beta_{1}-\beta_{2}\right) \chi}{\left(\alpha_{1}-\alpha_{2}\right)^{2}+\omega\left(\beta_{1}-\beta_{2}\right)^{2}}<0
\end{gathered}
$$

Comparison of (5) with (4) reveals that in response to a common supply shock, fiscal policy under coordination may be either more or less expansionary than under the Nash regime. 
Output and current account comparisons between the two regimes produce similar ambiguities.

These ambiguities arise because of two separate externalities that coordination internalizes.

First, domestic (foreign) fiscal policy has a beggar-thy-neighbor effect on foreign

(domestic) output. By internalizing this negative externality, fiscal policies will be less

expansionary under coordination than under the Nash regime. Second, coordinating

policymakers recognize ex ante that joint fiscal expansion will dampen the deterioration of

the current account by negating the bilateral deficit. Hence, fiscal policy under

coordination will be more expansionary than under the Nash regime. ${ }^{8}$ However, if $\beta_{2}$ is

"small", so that the output externality of fiscal policy dominates the current account

externality, fiscal policy under coordination will be less expansionary than under insular

policymaking. Consequently, a regime of fiscal policy coordination will produce more output

variance but less current account variance than a regime of insular fiscal policymaking. ${ }^{9}$

By substituting the expressions in (5) into (3), it can be shown that regardless of the

magnitude of $\beta_{2}$, the social loss under fiscal policy coordination is smaller than under insular policymaking.

In response to an asymmetric demand shock, optimal fiscal policies under the Nash regime, and the resulting output and current account expressions are

$$
\begin{aligned}
& g=-g^{*}=\frac{-\left(\alpha_{1}-\omega \beta_{1} \beta_{3}\right) \mu}{\alpha_{1}\left(\alpha_{1}+\alpha_{2}\right)+\omega \beta_{1}\left(\beta_{1}+\beta_{2}\right)} \\
& y=-y^{*}=\frac{\omega \beta_{1}\left[\beta_{1}+\beta_{2}+\beta_{3}\left(\alpha_{1}+\alpha_{2}\right)\right] \mu}{\alpha_{1}\left(\alpha_{1}+\alpha_{2}\right)+\omega \beta_{1}\left(\beta_{1}+\beta_{2}\right)}
\end{aligned}
$$

\footnotetext{
8 This result is analogous to the result in Rogoff (1985) whereby coordination induces greater monetary expansion due to the offsetting effects on exchange rate depreciation.

9 If domestic fiscal policy has a "locomotive" effect on foreign output and vice versa (if $\alpha_{2}>0$ ), then regardless of the magnitude of $\beta_{2}$, fiscal policy under coordination always will be more expansionary than under the Nash regime. By internalizing the positive externality their policy has on output in the other country, coordinating policymakers would be more expansionary than their insular counterparts. The output effect combined with the current account effect would make fiscal policy under coordination unambiguously more expansionary. Consequently, a regime of fiscal policy coordination would produce less output variance but more current account variance than a regime of insular fiscal policymaking.
} 


$$
\mathrm{CA}=-\mathrm{CA}^{*}=\frac{\alpha_{1}\left[\beta_{1}+\beta_{2}+\beta_{3}\left(\alpha_{1}+\alpha_{2}\right)\right] \mu}{\alpha_{1}\left(\alpha_{1}+\alpha_{2}\right)+\omega \beta_{1}\left(\beta_{1}+\beta_{2}\right)}
$$

The sign of the domestic fiscal response is ambiguous because the demand shock initially causes an increase in domestic output and a domestic current account surplus. Contractionary domestic fiscal policy would stabilize domestic output but would destabilize the domestic current account. Ex post, the domestic economy experiences an unambiguous output increase and current account surplus. Identically opposite results apply to the foreign country. Under fiscal policy coordination the resulting expressions are

$$
\begin{gathered}
\mathrm{g}=-\mathrm{g}^{*}=\frac{-\left[\alpha_{1}+\alpha_{2}-\omega \beta_{3}\left(\beta_{1}+\beta_{2}\right)\right] \mu}{\left(\alpha_{1}+\alpha_{2}\right)^{2}+\omega\left(\beta_{1}+\beta_{2}\right)^{2}} \\
y=-y^{*}=\frac{\omega\left(\beta_{1}+\beta_{2}\right)\left[\beta_{1}+\beta_{2}+\beta_{3}\left(\alpha_{1}+\alpha_{2}\right)\right] \mu}{\left(\alpha_{1}+\alpha_{2}\right)^{2}+\omega\left(\beta_{1}+\beta_{2}\right)^{2}} \\
C A=-C^{*}=\frac{\left(\alpha_{1}+\alpha_{2}\right)\left[\beta_{1}+\beta_{2}+\beta_{3}\left(\alpha_{1}+\alpha_{2}\right)\right] \mu}{\left(\alpha_{1}+\alpha_{2}\right)^{2}+\omega\left(\beta_{1}+\beta_{2}\right)^{2}}
\end{gathered}
$$

It can be shown that if $\beta_{2}$ is "small", domestic (foreign) fiscal policy is more contractionary (expansionary) under coordination than under insular policymaking. Recall that the demand shock causes an initial increase (decrease) in domestic (foreign) output. To stabilize domestic (foreign) output, the domestic (foreign) policymaker reduces (increases) domestic (foreign) government spending inducing an increase (decrease) in foreign (domestic) output. However, only under coordination do policymakers recognize ex ante the stabilizing effect their action has on output in the other economy. Consequently, domestic (foreign) fiscal policy is more contractionary (expansionary) under coordination than under the Nash regime. This implies that fiscal policy coordination provides more stability to output but less stability to the current account. By substituting the expressions in (7) into (3), it can be shown that regardless of the magnitude of $\beta_{2}$, the social loss under fiscal policy coordination is smaller than under insular policymaking. 
In sum, the need for fiscal flexibility depends both on the fiscal policy regime and the source of the shock. When $\beta_{2}$ is "small", stabilizing a common supply shock requires less expansionary fiscal policy under coordination than under insular policymaking. Hence, the need for fiscal flexibility is lower under the former regime. However, to respond optimally to an asymmetric demand shock, a regime of fiscal policy coordination requires more fiscal flexibility than its insular counterpart.

\section{Simulations}

The Federal Reserve Board's Multi-Country Model (MCM), which reports quarterly realizations of the endogenous variables, was used to ascertain the relative degree of fiscal policy flexibility required to stabilize shocks under insular and coordinated policymaking. ${ }^{10}$ It is assumed that EMU is comprised only of Germany, France, the United Kingdom, and Italy and that the exchange rates among these countries are irrevocably fixed.

Assume that authorities in each country want to stabilize deviations of output and the current account from target levels. As noted in Section 1, the primary objective of community-wide monetary policy under EMU will be price stability. This policy objective, which can be met exactly, is modelled by specifying that German monetary policy target the German price level. The monetary authorities of France, the United Kingdom, and Italy respond to keep their respective exchange rates fixed against the Deutschmark.

This leaves fiscal policy the task of stabilizing output and the current account. Thus, the social loss function in each country is

$$
\mathrm{U}_{\mathrm{i}}=\left(\mathrm{y}_{\mathrm{i}}-\overline{\mathrm{y}}_{\mathrm{i}}\right)^{2}+\omega_{\mathrm{i}}\left(\mathrm{CA} \mathrm{A}_{\mathrm{i}}-\overline{\mathrm{CA}}_{\mathrm{i}}\right)^{2}
$$

where $\bar{y}_{i}$ is the output target in Country $i$ and $\overline{\mathrm{CA}}_{\mathrm{i}}$ is the current account target in

Country i. Target values are assumed to be the baseline values, that is, values that would be realized in the absence of stochastic disturbances, in the MCM. Although Bredenkamp and

\footnotetext{
To For a current description of the MCM see Marquez (1993). For an older description see Edison, Marquez, and
} Tryon (1987). 
Deppler (1990) note that targeting the current account in a monetary union may be inappropriate, we use the current account as a proxy for a wealth target. Indeed, the current account is equal to the net accumulation of foreign wealth. ${ }^{11}$ Monetary and fiscal policies in the rest-of-the-world, which are assumed to be exogenous, do not respond to the shocks.

Minimizing (8) yields fiscal reaction functions that will be used in the simulations. To perform the simulations, policy multipliers and welfare weights on the current accounts need to be specified. The multipliers are derived from the MCM and are given in Tables 1 and 2. As can be seen in Table 1, German fiscal expansion, which raises German interest rates, lowers output in Germany's EMU partners. To maintain the parity with the Deutschmark, interest rates in the other EC countries rise, thereby reducing output. Fiscal expansions in the other EC countries raise output in partner countries due to the negligible effects these expansions have on interest rates.

The choice of welfare weights, the $\omega_{i}$ 's in (8), is somewhat arbitrary. Therefore, the adopted procedure follows Frankel and Rockett (1988) by using the welfare weight that Oudiz and Sachs (1984), who performed their simulations with the MCM, assign to the current account in the German social loss function. ${ }^{12}$ This is the value that the weight would have to have been to produce the actual values of output, inflation, and the current account observed during the 1980's. In addition, the current account weights of France, the United Kingdom, and Italy are assumed to be equal to the German current account weight.

Two regimes of fiscal policymaking are considered. Fiscal policy reaction functions in the first regime, the Nash regime, are derived under the assumption that the fiscal authority in each country minimizes its own social loss function. Before choosing policy responses, fiscal authorities observe initial output and current account deviations not only in their

\footnotetext{
1 Masson and Melitz (1991) use a current account target in their EMU simulations. Likewise, DeGrauwe (1990) uses the current account as a target in his analysis of fiscal policymaking under fixed exchange rates. Oudiz and Sachs (1984) and Frankel and Rockett (1988) use current account targets in simulations of monetary coordination under flexible exchange rates. Hughes Hallett and Vines (1991) employ a wealth target as a generalization from a current account target.

${ }^{2}$ This weight has a value of 1.9 .
} 
own country, but in the other countries as well. Therefore, these variables are part of each country's information set. Fiscal policy reaction functions in the Nash regime are presented in Appendix A1. As the German fiscal policy reaction function indicates, a German output expansion or current account deficit will induce contractionary German fiscal policy in the Nash regime. French, British, and Italian output expansions also induce contractionary German fiscal policy because of the small positive effect these increases have on German output. With some exceptions, the French, British, and Italian reaction functions exhibit similar characteristics.

Under fiscal policy coordination, the fiscal authority in each country minimizes the unweighted sum of all the social loss functions. Fiscal policy reaction functions in the coordinated regime are presented in Appendix A2. For example, the German fiscal policymaker under the coordinated regime considers social losses in the other EMU countries. Thus, the German fiscal response to German output and current account deviations should be relatively smaller in the coordinated regime than in the Nash regime. Comparing the German reaction function in Appendix A2 with that in Appendix A1 confirms this conclusion.

Two separate unexpected temporary shocks are considered: a ten percent increase in the price of oil and an increase in German private consumption equal to one percent of GDP. The shocks, which occur in the first quarter of 1993, cause the endogenous variables of the model to deviate from their baseline values. Fiscal policy in each country aims to stabilize deviations in output and the current account, and accordingly, is dictated by the reaction functions given in the appendix.

\section{Results}

As discussed above, the overall social loss in each country depends on the variances of output, the price level, and the current account around baseline values. In the simulations, German monetary policy insures that the German domestic price level never deviates from its 
baseline path. Monetary policy in France, the United Kingdom, and Italy insures that the franc/mark, pound/mark, and lira/mark parities respectively remain unchanged. Because of the flexible exchange rate with the rest-of-the-world, consumer price indices in the four European countries exhibit only minor fluctuations, and for the sake of brevity, are not reported.

Although social losses do not depend on changes in government spending, ascertaining the relative degree of fiscal flexibility that a regime of fiscal policy coordination requires is one of the main objectives of this paper. Therefore, Table 3 presents fiscal policy responses to the oil price shock. The numbers in Table 3 are the total variance in the government spending/GDP ratio in each country summed over eight quarters (beginning with the first quarter of 1993, the quarter in which the shock occurs). As can be seen, the variance of the government spending/GDP in Germany is greater under the coordinated regime than under the Nash regime. This simulation result contradicts the theoretical result found in Section 2 whereby the coordinated regime induces less fiscal activism than the Nash regime in response to a common supply shock. However, Table 3 also shows that the coordinated regime ind xces less variance in the government spending/GDP ratio in France, the United Kingdom, and Italy. Moreover, the total European variance in government spending/GDP ratios (the total reported at the bottom of the table) is 15 percent smaller under fiscal policy coordination than under insular policymaking. ${ }^{13}$

Tables 4 and 5 respectively report variances in real GDP and current accounts in the case of the oil price shock. As discussed in Section 2, the smaller response of fiscal policy under coordination induces more output variance but less current account variance than insular policymaking. Table 4 shows that although the theoretically predicted result for output is not found for France and Italy, it does hold for Germany and the United Kingdom. Moreover, the total European output variance is 58 percent higher under fiscal policy coordination than under the Nash regime. A stronger confirmation of the theory is found for

\footnotetext{
${ }^{3}$ Qualitatively similar results for the individual countries and for the European total were found for government spending and deficit levels. We report variances in government spending/GDP ratios which, because of their unitless characteristic, allow us to aggregate over the individual countries.
} 
the current account variance which, under fiscal policy coordination, falls for each individual country and hence, the European total. Therefore, the theoretical findings for a common supply shock are reasonably supported by the simulations.

The results in Tables 4 and 5 also reveal whether fiscal policy coordination is more desirable than insular policymaking in each country. In France and Italy, fiscal policy coordination clearly would be desirable due to the reductions it induces in output and current account variances. In Germany and the United Kingdom, fiscal policy coordination reduces current account variance but increases output variance. However, the social loss under fiscal policy coordination is lower in both countries as substitution of the results in Tables 4 and 5 into the social loss function reveals. Consequently, all EMU members would benefit from fiscal policy coordination in response to a common supply shock.

The results for the German private consumption shock begin with Table 6 . The analysis in Section 2 predicts that in the case of an asymmetric demand shock, the variance in government spending will be greater under fiscal policy coordination than under insular policymaking. Table 6 shows that fiscal responses in Germany and France support this result. Although the government spending/GDP variance in the United Kingdom and Italy falls under coordination, the changes from insular policymaking are small. Indeed, the total European variance in government spending/GDP ratios is 225 percent greater under fiscal policy coordination than under insular policymaking, a result that strongly supports the theory.

As discussed in Section 2, the greater response of fiscal policy under coordination induces less output variance but more current account variance than insular policymaking. Table 7 shows that although the output variance for the United Kingdom rises under coordination, the results for Germany, France, and Italy support the theoretical finding. Moreover, the total European output variance is 23 percent smaller under fiscal policy coordination than under insular policymaking. However, the results in Table 8 , in which the current account variance rises under fiscal policy coordination for only the United Kingdom, is not very supportive of the theory. Therefore, the simulations lend mixed support to the 
theoretical findings for an asymmetric demand shock.

Germany, France, and Italy all would prefer fiscal policy coordination to insular policymaking due to the reductions in output and current account variances the former regime induces. However, the United Kingdom would find fiscal policy coordination undesirable; the variances in UK output and current account both are lower under the Nash regime. Therefore, the hesitancy of the United Kingdom to join EMU could be justified on the grounds of macroeconomic stabilization.

The implications for the United States of fiscal policy coordination among EMU countries are shown in Tables 9 and 10. Two implications deserve mention. First, regardless of the source of the shock, fiscal policy coordination among EMU countries reduces US variances in output, the consumer price index, and the current account. This result is reasonable for the German private consumption shock: as shown in Tables 7 and 8, fiscal policy coordination in the simulations reduces the total European variance in output and the current account both, thereby reducing the variance in US macroeconomic variables (as shown in Table 10). However, as shown in Tables 4 and 5, fiscal policy coordination in response to the oil price shock induces an increase in the total European variance in output, thereby implying more spillover to the United States, but a decrease in the total European variance in the current account, thereby implying less spillover to the United State. Because fiscal policy coordination among EMU countries provides more overall macroeconomic stability to the United States (as shown in Table 9), it is likely that the current account effect outweighs the output effect.

Second, the magnitude of the spillovers, and hence the gains to the United States from fiscal policy coordination among EMU countries, is relatively small. This is apparent in Tables 9 and 10 in which the variances of US macroeconomic variables, even when EMU countries engage in insular fiscal policymaking, are relatively insignificant. ${ }^{14}$ Therefore, from the perspective of the United States, fiscal policy coordination among EMU countries is

14 The relatively large variance in the US current account in response to the oil price shock likely is caused by higher oil prices rather than fluctuations in European macroeconomic variables. 
desirable; however, the gains to the United States are likely to be small.

\section{Conclusion}

The paper has shown theoretically that the social loss under fiscal policy cocrdination is smaller than under insular policymaking. This result holds for a common supply shock and for an asymmetric demand shock. Consequently, when given a choice between insular policymaking and fiscal policy coordination, the fiscal authorities always should choose the latter regime. The simulation results in Section 4 support this theoretical result for the common supply shock. That is, in response to an oil price increase, Germany, France, the United Kingdom, and Italy all can realize smaller social losses by coordinating fiscal policies. With the exception of the United Kingdom, the simulation results also support the theoretical finding that fiscal policy coordination is welfare-improving in the case of an asymmetric demand shock.

Given that EC members, with the possible exception of the United Kingdom, may find fiscal policy coordination desirable, the above analysis holds other relevance for EMU. The paper has argued that the degree of policy activism required for macroeconomic s:abilization under fiscal policy coordination depends on the type of the stochastic disturbance. The paper showed theoretically and empirically that in response to a common supply shock, a regime of fiscal policy coordination may induce less variance in government spending, and therefore, less need for fiscal flexibility, than a regime of insular policymaking. However, the opposite result may hold in response to an asymmetric demand shock. Therefore, rules that inhibit fiscal flexibility, as proposed in the Delors Report, may be made less binding by fiscal policy coordination in response to a common supply shock. However, as also discussed in Bryson (1994), these rules may be counterproductive if coordinating fiscal authorities face an asymmetric demand shock.

The above simulations were performed under the assumption that fiscal policies were 
adjusted quarterly, an obvious distortion of reality. However, because the empirical results have a firm theoretical foundation, the qualitative results likely would be similar in an environrnent in which fiscal policies were adjusted less frequently. The issue of fiscal policy coordination under EMU is far from settled. Therefore, it would be beneficial if researchers with access to other multi-country models tested the robustness of the above conclusions. 
Table 1. Effects of a 1\% Fiscal Expansion on GDP. ${ }^{\mathrm{a}}$

\begin{tabular}{lcccl}
\hline & \multicolumn{4}{c}{ Effect On } \\
Expansion By & Germany & France & United Kingdom & Italy \\
Germany & 0.394 & -0.056 & -0.414 & -0.125 \\
France & 0.010 & 0.522 & 0.002 & 0.007 \\
United Kingdom & 0.010 & 0.005 & 0.895 & 0.005 \\
Italy & 0.006 & 0.004 & 0.001 & 0.458 \\
\hline
\end{tabular}

a. Percentage change in GDP from its baseline value in the quarter the expansion occurs.

Table 2. Effects of a 1\% Fiscal Expansion on the Current Account. ${ }^{\text {a }}$

\begin{tabular}{llccc}
\hline & \multicolumn{4}{c}{ Effect On } \\
Expansion By & Germany & France & United Kingdom & Italy \\
Germany & -0.153 & -0.708 & 0.075 & 0.161 \\
France & 0.046 & -0.695 & 0.028 & 0.015 \\
United Kingdom & 0.054 & 0.026 & -0.193 & 0.013 \\
Italy & 0.053 & -0.018 & 0.030 & -1.258 \\
\hline
\end{tabular}

a. Percentage change in the current account from its baseline value in the quarter the expansion occurs. 
Table 3. Variance in Government Spending/GDP Ratios. ${ }^{a}$

Oil Price Shock.

\begin{tabular}{lcc}
\hline Country & $\underline{\text { Nash }}$ & Coordination \\
Ciermany & 0.720 & 1.059 \\
France & 0.580 & 0.093 \\
UK & 0.078 & 0.020 \\
Italy & 0.004 & 0.002 \\
Total & 1.382 & 1.174 \\
\hline
\end{tabular}

$\bar{a}$. Measured as the absolute deviation from baseline. The numbers are the total variance in the government spending/GDP ratio summed over eight quarters.

Table 4. Variance in Output. ${ }^{\mathrm{a}}$

Oil Price Shock.

\begin{tabular}{lcc}
\hline Country & Nash & Coordination \\
Ciermany & 0.060 & 1.409 \\
France & 0.434 & 0.020 \\
UK & 1.077 & 1.243 \\
Italy & 0.122 & 0.005 \\
Total & 1.693 & 2.677
\end{tabular}

a Measured as percent deviation from baseline. The numbers are the total variance in output summed over eight quarters.

Table 5. Variance in Current Account. ${ }^{\mathrm{a}}$ Oil Price Shock.

\begin{tabular}{lrc}
\hline Country & Nash & Coordination \\
Germany & 15.209 & 9.568 \\
France & 396.081 & 62.566 \\
CK & 7.803 & 1.292 \\
Italy & 15.956 & 1.862 \\
Total & 435.049 & 75.289 \\
\hline
\end{tabular}

a. Current account expressed in billions of dollars. Measured as absolute deviation from baseline. The numbers are the total variance in the current account summed over eight quarters. 
Table 6. Variance in Government Spending/GDP Ratios. ${ }^{a}$ German Private Consumption Shock.

\begin{tabular}{lcc}
\hline Country & $\underline{\text { Nash }}$ & Coordination \\
Germany & 0.438 & 1.572 \\
France & 0.040 & 0.110 \\
UK & 0.049 & 0.045 \\
Italy & 0.005 & 0.004 \\
Total & 0.532 & 1.731 \\
\hline
\end{tabular}

a. Measured as the absolute deviation from baseline. The numbers are the total variance in the government spending/GDP ratio summed over eight quarters.

Table 7. Variance in Output. ${ }^{\mathrm{a}}$

German Private Consumption Shock.

\begin{tabular}{lcc}
\hline Country & $\underline{\text { Nash }}$ & Coordination \\
\hline Germany & 0.098 & 0.008 \\
France & 0.525 & 0.113 \\
UK & 0.941 & 1.361 \\
Italy & 0.359 & 0.003 \\
Total & 1.923 & 1.486 \\
\hline
\end{tabular}

a. Measured as percent deviation from baseline. The numbers are the total variance in output summed over eight quarters.

Table 8. Variance in Current Account. ${ }^{\mathrm{a}}$ German Private Consumption Shock.

\begin{tabular}{lrc}
\hline Country & $\underline{N a s h}$ & Coordination \\
Germany & 60.938 & 1.326 \\
France & 45.436 & 9.694 \\
UK & 15.981 & 17.670 \\
Italy & 2.713 & 0.151 \\
Total & 125.068 & 28.841 \\
\hline
\end{tabular}

a. Current account expressed in billions of dollars. Measured as absolute deviation from baseline. The numbers are the total variance in the current account summed over eight quarters. 
Table 9. Variance in US Macroeconomic Variables. ${ }^{a}$

Oil Price Shock.

Variable

Output

Consumer Price Index

Current Account $\underline{\text { Nash }}$

0.006

0.047

175.697
Coordination

0.001

0.022

72.864

a. Output and consumer price index measured as percent deviation from baseline. Current account expressed in billions of dollars and measured as absolute deviation from baseline. The numbers are the total variance in the respective variables summed over eight quarters.

Table 10. Variance in US Macroeconomic Variables. ${ }^{\text {a }}$ German Private Consumption Shock.

$\underline{\text { Variable }}$

$\underline{\text { Nash }}$

Coordination

Output

0.002

0.004

0.000

Consumer Price Index

5.523

0.000

Current Account

1.105

a. Output and consumer price index measured as percent deviation from baseline. Current account expressed in billions of dollars and measured as absolute deviation from baseline. The numbers are the total variance in the respective variables summed over eight quarters. 
Appendix A1: Fiscal Policy Reaction Functions in the Nash Regime

Germany

$$
\begin{aligned}
& \left(G_{t}-G G_{t}^{B}\right)=-1.973\left(G G D P_{t}-G G D P_{t}^{B}\right)+1.457\left(G C U R_{t}-G C U R_{t}^{B}\right)
\end{aligned}
$$

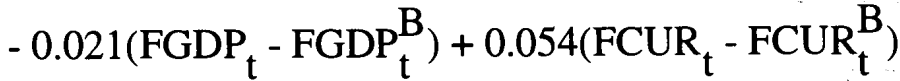

$$
\begin{aligned}
& -0.062\left(E_{G D P}-E_{t} \operatorname{EDP}_{t}^{B}\right)+0.026\left(E_{C U R}-E_{t} \operatorname{EUR}_{t}^{B}\right) \\
& -0.009\left(\operatorname{IGDP}_{t}-\operatorname{IGDP}_{\mathrm{t}}^{\mathrm{B}}\right)+0.049\left(\operatorname{ICUR}_{\mathrm{t}}-\operatorname{ICUR}_{\mathrm{t}}^{\mathrm{B}}\right) \\
& \left(F_{t}-F_{t}^{B}\right)=1.484\left(G G D P_{t}-G G D P_{t}^{B}\right)-1.096\left(G C U R_{t}-G C U R_{t}^{E i}\right) \\
& -0.422\left(F_{G D P}-F_{t} G_{t}^{B}\right)+1.069\left(F_{C U R}-F_{t} C_{t}^{B}\right) \\
& +0.020\left(\mathrm{EGDP}_{\mathrm{t}}-\mathrm{EGDP}_{\mathrm{t}}^{\mathrm{B}}\right)-0.008\left(\mathrm{ECUR}_{\mathrm{t}}-\mathrm{ECUR}_{\mathrm{t}}^{\mathrm{B}}\right. \text { ) } \\
& +0.010\left(\operatorname{IGDP}_{t}-\operatorname{IGDP}_{t}^{\mathrm{B}}\right)-0.053\left(\operatorname{ICUR}_{t}-\operatorname{ICUR}_{t}{ }^{\mathrm{B}}\right)
\end{aligned}
$$

United Kingdom

$$
\begin{aligned}
& \left(E_{t}-E_{t}^{B}\right)=-0.889\left(G G D P_{t}-G G D P_{t}^{B}\right)+0.656\left(G C U R_{t}-G C U R_{t}^{B}\right) \\
& -0.014\left(\text { FGDP }_{t}-\text { FGDP }_{t}^{B}\right)+0.035\left(\text { FCUR }_{t}-\text { FCUR }_{t}^{B}\right)
\end{aligned}
$$

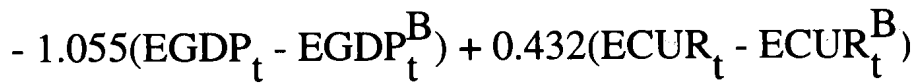

$$
\begin{aligned}
& -0.006\left(\operatorname{IGDP}_{t}-\operatorname{IGDP}_{t}^{\mathrm{B}}\right)+0.031\left(\mathrm{ICUR}_{t}-\operatorname{ICUR}_{\mathrm{t}}^{\mathrm{B}}\right) \\
& \text { Italy } \\
& \left(\mathrm{IG}_{\mathrm{t}}-\mathrm{IG}_{\mathrm{t}}^{\mathrm{B}}\right)=-0.264\left(\mathrm{GGDP}_{\mathrm{t}}-\mathrm{GGDP}_{\mathrm{t}}^{\mathrm{B}}\right)+0.195\left(\mathrm{GCUR}_{\mathrm{t}}-\mathrm{GCUR}_{\mathrm{t}}^{\mathrm{B}}\right) \\
& -0.007\left(F_{G D P}-F_{t} G D P_{t}^{B}\right)+0.019\left(F^{B} C U R_{t}-F^{B} R_{t}^{B}\right) \\
& -0.018\left(E G_{t}-\operatorname{EGDP}_{t}^{\mathrm{B}}\right)+0.007\left(\mathrm{ECUR}_{\mathrm{t}}-\mathrm{ECUR}_{\mathrm{t}}^{\mathrm{B}}\right) \\
& -0.143\left(\operatorname{IGDP}_{t}-\operatorname{IGDP}_{t}^{\mathrm{B}}\right)+0.750\left(\mathrm{ICUR}_{\mathrm{t}}-\mathrm{ICUR}_{\mathrm{t}}^{\mathrm{B}}\right)
\end{aligned}
$$

where $\mathrm{GG}=$ German government spending

$\mathrm{FG}=$ French government spending

$\mathrm{EG}=\mathrm{UK}$ government spending

IG = Italian government spending

GGDP = German GDP

FGDP $=$ French GDP

$\mathrm{EGDP}=\mathrm{UK}$ GDP

IGDP = Italian GDP

GCUR $=$ German current account

FCUR $=$ French current account

ECUR $=$ UK current account

ICUR = Italian current account

and where $\mathrm{X}^{\mathrm{B}}=$ is the baseline value of variable $\mathrm{X}$ 
Appendix A2: Fiscal Policy Reaction Functions in the Coordinated Regime

Germany

$\left(G_{t}-G G_{t}^{B}\right)=-0.847\left(G G D P_{t}-G G D P_{t}^{B}\right)+0.633\left(G C U R_{t}-G C U R_{t}^{B}\right)$

$+0.950\left(\mathrm{FGDP}_{\mathrm{t}}-\mathrm{FGDP}_{\mathrm{t}}^{\mathrm{B}}\right)+0.751\left(\mathrm{FCUR}_{\mathrm{t}}-\mathrm{FCUR}_{\mathrm{t}}^{\mathrm{B}}\right)$

$-0.028\left(E \operatorname{EDP}_{t}-\mathrm{EGDP}_{\mathrm{t}}^{\mathrm{B}}\right)+0.139\left(\mathrm{ECUR}_{\mathrm{t}}-\mathrm{ECUR}_{\mathrm{t}}^{\mathrm{B}}\right)$

$+0.141\left(\operatorname{IGDP}_{t}-\operatorname{IGDP}_{t}^{\mathrm{B}}\right)+0.070\left(\operatorname{ICUR}_{\mathrm{t}}-\mathrm{ICUR}_{\mathrm{t}}^{\mathrm{B}}\right)$

France

$\left(F_{t}-F_{t}^{B}\right)=0.619\left(G G D P_{t}-G G D P_{t}^{B}\right)-0.546\left(G C U R_{t}-G C U R_{t}^{B}\right)$

$-1.141\left(\mathrm{FGDP}_{\mathrm{t}}-\mathrm{FGDP}_{\mathrm{t}}^{\mathrm{B}}\right)+0.547\left(\mathrm{FCUR}_{\mathrm{t}}-\mathrm{FCUR}_{\mathrm{t}}^{\mathrm{B}}\right)$

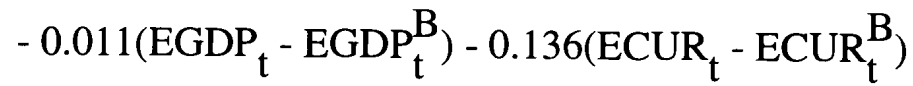

$-0.111\left(\operatorname{IGDP}_{t}-\operatorname{IGDP}_{\mathrm{t}}^{\mathrm{B}}\right)-0.075\left(\mathrm{ICUR}_{\mathrm{t}}-\mathrm{ICUR}_{\mathrm{t}}^{\mathrm{B}}\right)$

\section{United Kingdom}

$\left(E_{t}-E_{t}^{B}\right)=-0.417\left(G G D P_{t}-G G D P_{t}^{B}\right)+0.182\left(G C U R_{t}-G C U R_{t}^{B}\right)$

$+0.431\left(\mathrm{FGDP}_{\mathrm{t}}-\mathrm{FGDP}_{\mathrm{t}}^{\mathrm{B}}\right)+0.347\left(\mathrm{FCUR}_{\mathrm{t}}-\mathrm{FCUR}_{\mathrm{t}}^{\mathrm{B}}\right)$

$-1.033\left(E_{G D P}-E_{t} G_{t}{ }_{t}^{B}\right)+0.482\left(E_{C U R}-E_{t} C_{t}^{B}\right)$

$+0.056\left(\operatorname{IGDP}_{t}-\operatorname{IGDP}_{t}^{\mathrm{B}}\right)+0.034\left(\mathrm{ICUR}_{\mathrm{t}}-\mathrm{ICUR}_{\mathrm{t}}^{\mathrm{B}}\right)$

Italy

$\left(\mathrm{IG}_{\mathrm{t}}-\mathrm{IG}_{\mathrm{t}}^{\mathrm{B}}\right)=-0.118\left(\mathrm{GGDP}_{\mathrm{t}}-\mathrm{GGDP}_{\mathrm{t}}^{\mathrm{B}}\right)+0.054\left(\mathrm{GCUR}_{\mathrm{t}}-\mathrm{GCUR}_{\mathrm{t}}^{\mathrm{B}}\right)$

$+0.129\left(\mathrm{FGDP}_{\mathrm{t}}-\mathrm{FGDP}_{\mathrm{t}}^{\mathrm{B}}\right)+0.114\left(\mathrm{FCUR}_{\mathrm{t}}-\mathrm{FCUR}_{\mathrm{t}}^{\mathrm{B}}\right)$

$-0.015\left(\mathrm{EGDP}_{\mathrm{t}}-\mathrm{EGDP}_{\mathrm{t}}^{\mathrm{B}}\right)+0.006\left(\mathrm{ECUR}_{\mathrm{t}}-\mathrm{ECUR}_{\mathrm{t}}^{\mathrm{B}}\right)$

$-0.123\left(\operatorname{IGDP}_{t}-\operatorname{IGDP}_{t}^{\mathrm{B}}\right)+0.751\left(\operatorname{ICUR}_{\mathrm{t}}-\mathrm{ICUR}_{\mathrm{t}}^{\mathrm{B}}\right)$ 


\section{REFERENCES}

Bovenberg, A. Lans, Kremers, Jeroen and Masson, Paul, "Economic and Monetary Union in Europe and Constraints on National Budgetary Policies", International Monetary Fund Staff Papers 38 (June 1991), p. 374-398

Bredenkamp, Hugh and Deppler, Michael, "Fiscal Constraints of a Fixed Exchange Rate Regime", in Victor Argy and Paul De Grauwe (eds.), Choosing an Exchange Rate Regir.e: The Challenge for Smaller Industrial Countries, International Monetary Fund, Washington DC, 1990

Bryson, Jay, "Macroeconomic Stabilization Through Monetary and Fiscal Policy Ccordination: Implications for European Monetary Union", Open Economies Review, forthcoming

Currie, David, "European Monetary Union: Institutional Structure and Economic Performance", Economic Journal 102 (March 1992), p. 248-264

De Grauwe, Paul, "Fiscal Policies in the EMS - A Strategic Analysis", in Emil-Maria Claassen (ed.), International and European Monetary Systems, Praeger, New York, 1990

Edison, Hali, Marquez, Jaime and Tryon, Ralph, "The Structure and Properties of of the Federal Reserve Board Multicountry Model", Economic Modelling 4 (April 1987)

Emerson, Michael, Gros, Daniel, Italianer, Alexander, Pisani-Ferry, Jean, and Reichenbach, Horst, One Market, One Money: An Evaluation of the Potential Benefits and Costs of Forming an Economic and Monetary Union, Oxford University Press, Oxford, 1992

Frankel, Jeffrey and Rockett, Katharine, "International Macroeconomic Policy Coordination When Policymakers Do Not Agree on the True Model", American Economic Review 78 (1988), p. $318-340$

Hughes Hallett, Andrew and Vines, David, "Adjustment Difficulties Within a European Monetary Union: Can They Be Reduced?", in John Driffill and Massimo Beber (eds.), A. Currency for Europe, Lothian Foundation Press, London, 1991

Hughes Hallett, Andrew and Vines, David, "On the Possible Costs of European Monetary Union", The Manchester School of Economic and Social Studies 61 (March 1993), p. 35-64

Marquez, Jaime, "Quantifying North-South Interdependencies with MCM Simulations", in D. Vines and D. Currie (eds.), North-South Linkages and International Macroeconomic Policy, Cambridge University Press, Cambridge, forthcoming

Masson, Paul and Melitz, Jacques, "Fiscal Policy Independence in a Monetary Union", Open Economies Review 2 (1991), p. 113 - 136

Masson, Paul and Taylor, Mark, "Fiscal Policy Within Common Currency Areas", Journal of Common Market Studies 31 (March 1993), p. 29-44

Melitz, Jacques, "Brussels on a Single Money", Open Economies Review 2 (1991), p. 323-336

Oudiz, Gilles and Sachs, Jeffrey, "Macroeconomic Policy Coordination Among the Industrial Countries", Brookings Papers on Economic Activity (1984), p. 1-64 
Rogoff, Kenneth, "Can International Monetary Policy Coordination Be Counterproductive?", Journal of International Economics 18 (1985), p. 199-217

Thygesen, Niels, "The Relationship Between Economic and Monetary Integration: EMU and National Fiscal Policy" in Daniel Gros and Niels Thygesen (eds.), European Monetary Integration: From EMS to EMU, Longman, London, 1992

Wyplosz, Charles, Monetary Union and Fiscal Policy Discipline", European Economy 44 (October 1991), p. 165-184 


\section{International Finance Discussion Papers}

IFDP

Number

467

466

465

464

463

462 When do long-run
reliable results?

Fiscal Policy Coordination and Flexibility Under European Monetary Union: Implications for Macroeconomic Stabilization

The Federal Funds Rate and the Implementation of Monetary Policy: Estimating the Federal Reserve's Reaction Function

Understanding the Empirical Literature on Purchasing Power Parity: The Post-Bretton Woods Era

Inflation, Inflation Risk, and Stock Returns

Are Apparent Productive Spillovers a Figment of Specification Error?

$\underline{1993}$

$461 \quad$ Fluctuating Confidence and Stock-Market Returns

460 Dollarization in Argentina

459

458

457

456

455
Union Behavior, Industry Rents, and Optimal Policies

A Comparison of Some Basic Monetary Policy Regimes: Implications of Different Degrees of Instrument Adjustment and Wage Persistence

Cointegration, Seasonality, Encompassing, and the Demand for Money in the United Kingdom

Exchange Rates, Prices, and External Adjustment in the United States and Japan

Political and Economic Consequences of Alternative Privatization Strategies
Jay H. Bryson

Allan [). Brunner

Hali J. Edison Joseph E. Gagnon William R. Melick

John Ammer

Susanto Basu John S. Fernald

Jon Faust Eric M. Leeper

Alexander David

Steven B. Kamin

Neil R. Ericsson

Phillip Swagel

Dale W. Henderson

Warwick J. McKibbin

Neil R. Ericsson

David F. Hendry

Hong-Anh Tran

Peter Hooper

Jaime Marquez

Catherine L. Mann

Stefanie Lenway

Derek Utter

Please address requests for copies to International Finance Discussion Papers, Division of International Finance, Stop 24, Board of Governors of the Federal Reserve System, Washington, D.C. 20551. 


\section{International Finance Discussion Papers}

IFDP

Number

454

453

452

451

450

449

448

447

446

445 Industry Restructuring and Export Performance:

Evidence on the Transition in Hungary

444 Exchange Rates and Foreign Direct Investment:

A Note

443 Global versus Country-Specific Productivity Shocks and the Current Account

442 The GATT's Contribution to Economic Recovery in Post-War Western Europe

441 A Utility Based Comparison of Some Models of Exchange Rate Volatility

440

$\underline{\text { Titles }}$

$\underline{1993}$

Fiscal Policy Coordination Implications for

Long-term Banking Relationships in General

The Role of Fiscal Policy in an Incomplete

Markets Framework

Internal Funds and the Investment Function

Data

Macroeconomic Risk and Asset Pricing: Estimating

Near observational equivalence and unit root

Market Share and Exchange Rate Pass-Through in World Automobile Trade

Cointegration Tests in the Presence of Structural $\underline{\text { Author(s) }}$

Measuring International Economic Linkage with Stock Breaks
Joseph E. Gagnon

Mark D. Unferth

Jay H. Bryson

Michael S. Gibson

Charles P. Thomas

Guy V.G. Stevens

John Ammer

Jianping Mei

John Ammer

Jon Faust

Robert C. Feenstra Joseph E. Gagnon Michael M. Knetter

Valerie J. Chang Catherine L. Mann

Guy V.G. Stevens

Reuven Glick Kenneth Rogoff

Douglas A. Irwin

Kenneth D. West

Hali J. Edison

Dongchul Cho

Julia Campos

Neil R. Ericsson

David F. Hendry 